\title{
TAX AND TRANSFER POLICIES AND THE FEMALE LABOR SUPPLY IN THE EU
}

Klára Kalíšková

Charles University

Center for Economic Research and Graduate Education

Academy of Sciences of the Czech Republic

Ec onomics Institute
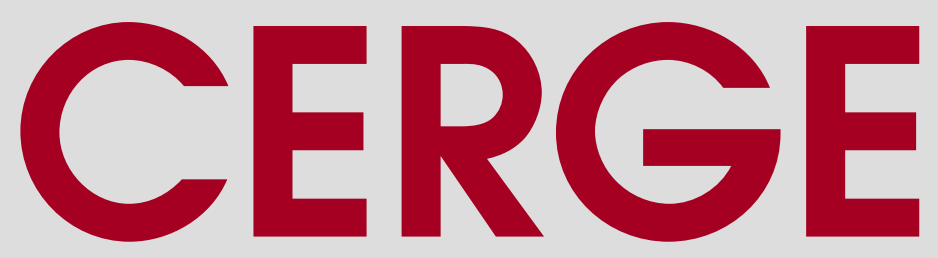


\section{Working Paper Series 524 (ISSN 1211-3298)}

\section{Tax and Transfer Policies and the Female Labor Supply in the EU}

Klára Kalíšková

CERGE-EI

Prague, December 2014 
ISBN 978-80-7343-329-1 (Univerzita Karlova. Centrum pro ekonomický výzkum a doktorské studium)

ISBN 978-80-7344-321-4 (Akademie věd České republiky. Národohospodářský ústav) 


\title{
Tax and Transfer Policies and the Female Labor Supply in the EU*
}

\author{
Klára Kalíšková ${ }^{\dagger}$ \\ CERGE-EI ${ }^{\ddagger}$
}

\begin{abstract}
This study contributes to the female labor supply responsiveness literature by measuring the effect of tax-benefit policies on female labor supply based on a broad sample of 26 European countries in 2005-2010. The tax-benefit microsimulation model EUROMOD is used to calculate the measure of extensive margin work incentives - the participation tax rate, which is then used as the main explanatory variable in a female participation equation. This allows me to deal with the endogeneity of income in a new way by a simulated instrumental variable based on a fixed EU-wide sample of women. Results suggest that a 10 percentage point increase in the participation tax rate decreases the female employment probability by 2 percentage points. The effect is higher for single mothers, for women in the middle of the skills distribution, and in countries that have lower rates of female participation.
\end{abstract}

Tato studie přispívá $\mathrm{k}$ literatuře zabývající se elasticitou nabídky práce žen tím, že zkoumá dopady daňově-dávkových politik na nabídku práce žen na základě mikroekonomických dat z 26 evropských zemí z let 2005 až 2010. Mikrosimulační model EUROMOD je využit $\mathrm{k}$ výpočtu ukazatele pracovních motivací-participační daňové sazby, která se pak používá jako hlavní vysvětlující proměnná v participační rovnici. Tento přístup umožňuje vypořádat se s endogeneitou př́ímů novým způsobem prostřednictvím simulované instrumentální proměnné, která je vytvořena na základě vzorku žen z celé EU. Výsledky naznačují, že nárůst participační daňové sazby o 10 procentních bodů snižuje pravděpodobnost zaměstnanosti žen o 2 procentní body. Efekt je vyšší u svobodných matek, pro ženy se středním vzděláním, a v zemích, které mají nižší míru zaměstnanosti žen.

JEL classification: C25, H24, H31, J22

Keywords: female labor supply, tax and benefit system, Europe, instrumental variable

\footnotetext{
*This research was financially supported by grant GB14-36154G from the Czech Science Foundation and by an ERSTE Foundation Fellowship for Social Research 2012/2013. The results presented here are based on EUROMOD version F6.0+. EUROMOD is maintained, developed and managed by the Institute for Social and Economic Research (ISER) at the University of Essex, in collaboration with national teams from the EU member states. EUROMOD relies on micro-data from 27 different countries. These are EU-SILC UDB datasets made available by Eurostat; Spanish SILC 2008 data made available by the Spanish Statistical Office; Italian SILC 2008 data made available by the Italian Statistical Office; Austrian SILC 2008 data made available by Statistics Austria; and United Kingdom Family Resources Survey 2008 data made available by the UK Data Archive. All errors remaining in this text are the responsibility of the author.

${ }^{\dagger}$ Email: klara.kaliskova@cerge-ei.cz

${ }^{\ddagger}$ CERGE-EI, a joint workplace of Charles University and the Economics Institute of the Academy of Sciences of the Czech Republic, Politickych veznu 7, 11121 Prague, Czech Republic.
} 


\section{Introduction}

The impact of tax-benefit systems on female labor supply has important consequences for an optimal design of tax and transfer policies. Labor supply elasticities have been widely studied in the economic literature, with a major challenge of this literature being the endogeneity of income. ${ }^{1}$ The literature on the responsiveness of labor supply decisions to tax and benefit changes can be separated into three main groups: structural models, reduced-form estimation, and grouped data estimation. Most labor supply elasticity estimates come from the structural literature that builds on a family labor supply model (see e.g. Bargain, Orsini, \& Peichl, 2014; Blundell, Duncan, McCrae, \& Meghir, 2000; Hoynes, 1996; van Soest, 1995). A second group of studies uses a specific tax or transfer reform in the reducedform estimation of labor supply responsiveness (see e.g. Eissa \& Liebman, 1996; Meyer \& Rosenbaum, 2001; Saez, Matsaganis, \& Tsakloglou, 2012). Finally, the grouped data literature identifies the labor supply elasticities by estimating groupaverage regressions over a long time period (see e.g. Blau \& Kahn, 2007; Causa, 2009; Blundell, Duncan, \& Meghir, 1998; Devereux, 2004).

Researchers usually seek for exogenous variation in income provided by tax and transfer reforms or by non-linearities in tax-transfer schedules. However, modeling tax-benefit systems for more than one country in a harmonized way has been largely limited by the complex nature of tax and transfer schedules. Therefore, the literature is highly concentrated on the US, the UK, and other developed economies of Western Europe, while there is little evidence for other countries, including the new EU member states. Moreover, the estimated magnitudes of female labor supply elasticities vary greatly across studies (for a survey, see Blundell \& Macurdy, 1999; Keane, 2011; Meghir \& Phillips, 2008).

This study brings several contributions to the female labor supply elasticity literature. Using the tax-benefit microsimulation model EUROMOD, I estimate

\footnotetext{
${ }^{1}$ Both labor and non-labor income are potentially endogenous to the labor supply. People have different unobserved characteristics (taste for leisure, ability, willingness to work hard, etc.) that affect their probability of being employed, their wages, and the size of non-labor income.
} 
the effect of tax-benefit policies on female labor supply based on a sample of 26 European countries in 2005-2010. This allows me to study the female labor supply responsiveness across countries and groups of women in a comparable way and at the same time control for both time-invariant and time-varying country-level unobserved factors. Further, this paper uses a new approach to deal with the endogeneity of income by using a group-level simulated instrumental variable based on a fixed EU-wide sample of women.

This study focuses on the extensive margin of female labor supply, because the responsiveness of female labor supply was found to be driven mainly by participation choices (Blundell et al., 1998; Keane, 2011). ${ }^{2}$ Unlike previous literature, which uses net wage and non-labor income as the main explanatory variables, the main explanatory variable in this study is a measure of the extensive margin work incentives - the participation tax rate (PTR). The PTR is defined as a proportion of lost earnings that is compensated for by lower taxes and higher benefits when not in paid work, and it thus describes the (dis)incentives provided by the tax-transfer system for the participation decision. The use of the PTR allows me to capture of the joint effect of taxes and transfers on female participation decisions and to deal with the endogeneity and measurement error in income by using a simulated instrumental variable. ${ }^{3}$

The instrumental variable for the PTR used in this study exploits variation in the PTR driven by changes in tax-transfer policies, while it eliminates the variation in the PTR caused by behavioral responses to these tax-transfer changes. In particular, the individual-level PTR is instrumented with a group-level measure of tax and transfer systems that is created based on a fixed EU-wide sample of women. This sample is created from a pooled dataset of all EU countries by taking a random sample of approximately 27,000 women. The instrumental variable for a

\footnotetext{
${ }^{2}$ In accordance with previous literature, I refer to the decision of working or not as the participation decision (see, e.g. Meghir \& Phillips, 2008). It should not be confused with labor force participation (being in a labor force or not, including the unemployed).

${ }^{3}$ Note that the use of the participation tax rate in the labor supply equation itself does not solve the problem of income endogeneity, because the PTR is a function of family income.
} 
woman with given characteristics, ${ }^{4}$ living in country $c$ and year $t$ is calculated as an average PTR of women from the fixed EU-wide sample who have the same characteristics and whose PTR is computed based on the tax-transfer system of country $c$ in year $t$. Therefore, the only variation in the IV stems from differences in tax and transfer policies across EU countries, over time, and across groups of women. This instrumental variable approach builds on the simulated IV approach used in the health economics literature (Currie \& Gruber, 1996; Cutler \& Gruber, 1996), but is also related to the simulated IV of Moffitt and Wilhelm (2000), Gruber and Saez (2002), or Dahl and Lochner $(2012)^{5}$ and to the grouped data literature.

This paper takes advantage of recent developments in multinational microsimulation models that allow researchers to model the tax and benefit systems for a large set of countries in a comparable way. It uses the EU-wide microsimulation model EUROMOD ${ }^{6}$ to calculate participation tax rates at the individual level for 26 EU countries in 2005-2010. The rich structure of the data enables the studying of the heterogeneity in female labor supply responsiveness across countries and groups of women while controlling for time-invariant country-specific characteristics (such as culture and informal institutions), but also for time-varying country-level unobserved factors (such as country-level economic shocks, changes in preferences for work or family policies).

Multinational microsimulation models have so far been used mainly to describe the differences in the tax and transfer systems across countries, and to my knowledge, Bargain et al. (2014) is the only study that uses a multinational microsimulation model in the labor supply elasticity estimation, and is thus closest to the

\footnotetext{
${ }^{4}$ Characteristics include education level, the presence of children of different ages, and marital status.

${ }^{5}$ These studies simulate instrumental variables based on the pre-reform characteristics of the affected individuals to which they apply the post-reform tax and transfer schedules. My instrumental variable works in a similar way, but I apply the tax and transfer schedules to the fixed sample of individuals with similar characteristics in order to minimize the effect of composition changes across countries and time. See Section 2.2 for details.

${ }^{6}$ EUROMOD is a tax-benefit microsimulation model for all EU member states. In this paper, EUROMOD version F6.0+ is utilized. EUROMOD is maintained, developed and managed by the Institute for Social and Economic Research (ISER) at the University of Essex, in collaboration with national teams from the EU member states. See https://www.iser.essex.ac.uk/euromod.
} 
present study. They use the microsimulation models TAXSIM and EUROMOD to compare labor supply elasticities of men and women in the U.S. and 17 European countries. Compared to Bargain et al. (2014), this study takes advantage of a newer version of the EUROMOD model, which includes a larger sample of countries (mainly from the post-communist countries) and a much longer time span, while I also take a different estimation approach. My methodology is based on a reduced-form estimation combined with an instrumental variable approach, while Bargain et al. (2014) use a structural model. An advantage of the present study over the structural models is that it does not require any assumptions on preferences (including the form of utility function and the choice set for working hours). However, it does require a sufficient amount of changes in the tax and transfer policies for identification. In Section 2.2, I argue that there was indeed enough policy variation in the EU countries between 2005 and 2010.

My results suggest that a 10 percentage point increase in the participation tax rate decreases the female employment probability by 2 percentage points. The implied participation elasticity with respect to the PTR is 0.08 - a $10 \%$ increase in the participation tax rate decreases the female employment rate by $0.8 \%$. I also analyze the heterogeneity of the response across groups of women with different characteristics and find that the effect is substantially higher for women with secondary education (an elasticity of 0.16 , compared to an elasticity of 0.04 for primary and tertiary-educated women) and women with small children. Consistent with previous findings, the highest elasticity is found for single mothers (0.32). Finally, the use of a multinational microsimulation model allows for a comparison of female participation elasticities across groups of countries in a harmonized way. I find that the responsiveness does differ substantially across countries, and that the countries with the lowest female participation rates have the highest participation elasticity. 


\section{Methodology}

\subsection{The participation tax rate}

This section introduces basic notation and explains the role of the participation tax rate in female participation decisions. Let's assume that each woman has a fixed earnings potential $e_{w}^{p}$ and fixed costs of work $q_{w}$ (including a disutility from work, a value of lost home production, child care costs, etc.). She chooses between working $\left(e_{w}=e_{w}^{p}\right)$ and not working $\left(e_{w}=0\right)$ to maximize the household's utility. ${ }^{7}$

The effect of taxes and transfers on family income is captured by a tax-transfer function $T\left(e_{m}, e_{w}, \rho\right)$, which represents net taxes paid as a function of both spouses' earnings ( $e_{m}$ denotes earnings of the woman's spouse) and parameters of the taxtransfer system $(\rho)$. Therefore, the female participation decision is based on a comparison of costs of work and net gain from entering the labor market, which is defined as gross earnings less net taxes that the woman has to pay while in paid work on top of net taxes that she pays out of work. Therefore, the woman decides to enter the labor market if:

$$
q_{w} \leq e_{w}^{p}-\left[T\left(e_{m}, e_{w}^{p}, \rho\right)-T\left(e_{m}, 0, \rho\right)\right]
$$

The participation decision can then be expressed in terms of the participation tax rate:

$$
P T R \equiv \frac{\left[T\left(e_{m}, e_{w}^{p}, \rho\right)-T\left(e_{m}, 0, \rho\right)\right]}{e_{w}^{p}} \leq \frac{e_{w}^{p}-q_{w}}{e_{w}^{p}}
$$

where the PTR describes the proportion of lost earnings that is compensated by lower taxes and higher benefits when not in paid work.

\footnotetext{
${ }^{7}$ Married and cohabiting women are assumed to be secondary earners; their labor force participation decisions follow their spouses' decisions, while single women are the primary and only potential earner in a household. I also assume here that spouses pool their resources, which is a standard assumption of a unitary model. While some studies question this assumption, the unitary model is still widely used in the labor supply literature (see e.g. Blundell, Pistaferri, \& Saporta-Eksten, 2012) and some recent empirical studies supported the validity of a unitary model (see, e.g. Bargain et al., 2014).
} 


\subsection{Estimation approach}

The model from the previous section provides a basis for the estimation approach used in this paper. I estimate the effect of a widely used work incentive measurethe participation tax rate- on the labor supply decisions of women. The participation equation has the following form:

$$
E m p l_{i c t}=\alpha P T R_{i c t}+\beta^{\prime} X_{i c t}+\gamma_{t}+\gamma_{c}+\left(\gamma_{c t}\right)+\epsilon_{i c t},
$$

where $E m p l i c t$ is the employment dummy, $P T R_{\text {ict }}$ is the participation tax rate, and $X_{i c t}$ represents the set of observable characteristics including age, education, marital status, number of household members, dummy variables for the presence of spouse, for children of certain ages (children aged 1, 2, 3, 4-5, 6-9, 10-15, and no children below 16), and for elderly in the household, and characteristics of spouse if present (education and economic status). I also include country fixed effects $\left(\gamma_{c}\right)$ and year fixed effects $\left(\gamma_{t}\right)$, while in most specifications all country-year fixed effects $\left(\gamma_{c t}\right)$ are included. Therefore, I allow for changes in the country-specific fixed effects, which capture unobserved country-specific tastes for work, cultural norms, gender-role attitudes, labor market conditions, or family policies.

I deal with possible endogeneity and measurement error in the PTR by using a simulated instrumental variable. ${ }^{8}$ The instrument for the PTR represents a grouplevel measure of the tax-transfer work incentives which is created based on a fixed sample of women from the whole EU. This method builds on the simulated instrument approach used in the health economics literature (Currie \& Gruber, 1996; Cutler \& Gruber, 1996), but is also related to the simulated IV used in the literature on responsiveness towards tax and transfer changes (Dahl \& Lochner, 2012; Gruber \& Saez, 2002; Moffitt \& Wilhelm, 2000).

The instrumental variable for the PTR is created in three steps. First, I take

\footnotetext{
${ }^{8}$ The participation tax rate is a function of a woman's and her husband's income (see equation 2 ). Therefore, it can be affected by the standard endogeneity and measurement error problems of income in the labor supply equation.
} 
a random sample of 27,000 women (denoted by a subscript $j$ ) from the pooled sample of the $26 \mathrm{EU}$ countries in $2007 .{ }^{9}$ The first step provides a sample of women with fixed demographic characteristics and fixed income distribution. Second, I calculate the participation tax rate $P T R_{j c t}$ for each woman $j$ from this fixed EUwide sample applying country $c$ and year $t$ 's tax and transfer system. I repeat this PTR calculation for each country-year cell. Therefore, for each woman in the fixed EU-wide sample, I have 126 calculated PTRs, where each PTR corresponds to one country-year cell. ${ }^{10}$ To avoid problems with income-level differences across the EU countries which might negatively affect the calculated $P T R_{j c t}$, I adjust incomes of women from the fixed EU-wide sample to correspond to the level of incomes in country $c .^{11}$

Third, the instrumental variable for a woman $i$ from group $g$, country $c$, and year $t$ is constructed as an average $P T R_{j c t}$ of women from the fixed EU-wide sample who belong to group $g .{ }^{12}$ Therefore, the only variation in this group-level IV stems from variation in tax and transfer systems across EU countries, over time, and across groups of women. The possible endogeneity and measurement error in the PTR are filtered out using the sample of women with fixed characteristics and fixed income distribution.

The simulated instrument is used in a 2SLS estimation described by the following equations:

\footnotetext{
${ }^{9}$ A sample of 27,000 women seems to be sufficiently large as to provide a reasonably strong IV and EUROMOD is not meant to work with much larger samples. I have also conducted a robustness check with a substantially smaller sample of 17,000 women, but the results were largely unchanged.

${ }^{10}$ There are 126 country-year cells used in the estimation, because not all 26 countries are observed for all 6 years between 2005 and 2010. For details, see Section 3.1.

${ }^{11}$ I assign each woman in the fixed EU-wide sample a quantile in the income distribution of her own country, and then change her income to correspond to the average income in that quantile, but in the income distribution of country c. I create very detailed income distributions with 400 income quantiles in each country. I also adjust incomes of all household members the same way, because their incomes potentially affect the PTR computation as well.

${ }^{12}$ There are in total 30 groups that are defined based on three educational categories (primary, secondary, and tertiary education), five categories according to the presence of children of various ages (children aged 1-3, 4-5, 6-9, 10-15, and no children below 16) and two categories by marital status (married and unmarried). Therefore, the IV for a married childless woman with tertiary education living in Germany in 2008 is calculated as an average PTR of women from the fixed EUwide sample who are also married, childless, and tertiary educated, and whose PTR is calculated based on the German tax-transfer system in 2008.
} 


$$
\begin{gathered}
P T R_{i c t}=\lambda P T R_{-} I V_{i c t}+\theta^{\prime} X_{i c t}+\gamma_{t}+\gamma_{c}+\left(\gamma_{c t}\right)+u_{i c t} \\
E m p l_{i c t}=\delta \widehat{P T R}_{i c t}+\phi^{\prime} X_{i c t}+\gamma_{t}+\gamma_{c}+\left(\gamma_{c t}\right)+e_{i c t}
\end{gathered}
$$

where $P T R_{-} I V_{i c t}$ is the instrumental variable for the PTR, $\widehat{P T R}_{i c t}$ denotes the predicted PTR from the first stage regression, and $\delta$ denotes the coefficient of interest.

The identification of female labor supply elasticities in this paper is based on tax and transfer changes that took place in the 26 EU countries between 2005 and 2010. Indeed, there were several reforms of tax and transfer schedules in this time period including some major reforms of tax systems - tax base allowances reform in Belgium in 2008, a flat tax reform in the Czech Republic in 2008, tax system changes in Denmark in 2010, an increase in the number of tax brackets in Spain in 2007, etc. Benefit schedules in the EU countries also underwent several important changes including the introduction of an allowance for school children in Belgium in 2006, reforms of housing and child benefits in the Czech Republic in 2007 and 2008, increased generosity of the universal child benefit and the reform of education benefits in Germany in 2008 and 2009, extensions to the large family benefit in Greece in 2006 and 2008, the introduction of a Solidarity labor income benefit in France in 2009, the reform of child benefit in Lithuania in 2009, etc.

\section{Data and microsimulation of taxes and benefits}

\subsection{Data and sample selection}

The empirical analysis makes use of the tax-benefit microsimulation model EUROMOD, version F6.0+. The EUROMOD model is largely based upon harmonized EU-SILC data ${ }^{13}$ (that are further adjusted for microsimulation purposes) combined with a detailed tax-benefit calculator. The model utilizes detailed information on

\footnotetext{
${ }^{13}$ For most countries EU-SILC UDB data are used for microsimulation, but for some countries national SILC data are utilized, while the Family Resource Survey data are used for the UK.
} 
household composition, characteristics of household members, and their incomes from the micro data, and creates common definitions of income concepts and assessment units to allow for a very detailed and harmonized micro-level calculation of taxes and benefits (for details on the EUROMOD project, see Sutherland, 2007). This makes EUROMOD a very suitable instrument for computing participation tax rates in a harmonized way for the EU countries.

The EUROMOD model covers all 27 countries of the EU, but I exclude Malta from the analysis, because the Maltese data have serious shortages. ${ }^{14}$ I utilize tax-transfer schedules that were in force in 2005 to 2010 and are available in the EUROMOD, version F6.0+. The EUROMOD model covers some countries only for 2006-2010 and some countries only for 2007-2010, because they joined the EUROMOD project only in 2006 or 2007. Moreover, while EUROMOD computes taxes and transfers for all the above mentioned years, the EUROMOD input data are available only for selected years. Computation of taxes and transfers for the years that do not have the corresponding input data is based on data from previous years with updated incomes. An overview of country-year cells, for which the tax-transfer computations are available and for which the EUROMOD input data are available, is provided in Appendix Table A.1. ${ }^{15}$

These country-year combinations, which have tax-transfer computations in EUROMOD but do not have the input data available, cannot be directly used in the estimation, because actual participation decisions of women for these country-year cells are not observed. However, the EUROMOD can be used to calculate the participation tax rates for all available country-year combinations, and then these participation tax rates can be assigned to individuals in the EU-SILC data, where the participation decisions are available. Participation tax rates computed within

\footnotetext{
${ }^{14}$ Maltese data does not include exact age information, but report age only in 5-year age bands, which is a serious limitation for female labor supply analysis, mainly because we cannot identify the exact age of children in a family.

${ }^{15}$ Official country abbreviations are used throughout the paper: Austria (AT), Belgium (BE), Bulgaria (BG), Cyprus (CY), Czech Republic (CZ), Germany (DE), Denmark (DK), Estonia (EE), Spain (ES), Finland (FI), France (FR), Greece (GR), Hungary (HU), Ireland (IE), Italy (IT), Lithuania (LT), Luxembourg (LU), Latvia (LV), Netherlands (NL), Poland (PL), Portugal (PT), Romania (RO), Sweden (SE), Slovenia (SI), Slovakia (SK), United Kingdom (UK).
} 
the EUROMOD are imputed to the EU-SILC data based on reported incomes and household characteristics using propensity score matching. ${ }^{16}$ The imputation should be very precise given the fact that the PTR is merely a function of incomes and other observable characteristics of individuals in a household.

Nevertheless, the quality of matching is examined in Section 4.3, where estimation results based on the EUROMOD data are compared to those based on the EU-SILC data with imputed participation tax rates. Since the quality of matching is indeed good, the main results presented in the paper are those based on the EU-SILC data with the imputed PTR. This allows me to take advantage of all available country-year cells in EUROMOD and substantially improves the identification strategy.

I restrict the sample to prime-aged women (aged 25-55), and I exclude women in full-time education, pensioners, disabled, women with a new-born child (younger than 1 year of age), ${ }^{17}$ and those with missing values for education. I also exclude the self-employed from the analysis (all women who have more than $30 \%$ of their work income from self-employment), because the quality of reporting of self-employment income in the micro-data sources is generally limited and varies largely across countries (Immervoll, 2004). Excluding self-employed women is a common practice in a majority of the female labor supply elasticities papers (see, e.g. Bargain et al., 2014). The analysis includes both women living in couples (married or cohabiting) and single women.

\footnotetext{
${ }^{16}$ The propensity score matching procedure matches women in the EUROMOD data with those in EU-SILC within each country-year cell based on their income, marital status, income of the partner (if present), dummy variables for presence of children of various ages (children aged 1, $2,3,4-5,6-9,10-15$, and no children below 16) and a dummy for elderly household members. Each woman in the SILC data is assigned a closest neighbor from the EUROMOD data and the corresponding PTR is imputed. To maintain consistency, the PTR is imputed to the EU-SILC data even for those years for which the EUROMOD input data are available.

${ }^{17}$ Children aged 0 are dropped from the EUROMOD dataset in order to align demographic variables with the income reference period for the computation of benefits (in most countries, the income reference period of the data is the calendar year preceding the survey).
} 


\subsection{Participation tax rate calculations}

The participation tax rate is defined as the difference between net taxes paid when the woman works and when she does not work over her gross wage, while the economic status and incomes of all other household members are fixed. Therefore, to calculate the PTR, I need to compute taxes and benefits for all household members for two hypothetical scenarios — when the woman works and when she does not work. For the non-working women, this requires some assumptions about their potential earnings. I impute monthly wages for all women (both working and non-working) using Heckman's two step procedure. ${ }^{18}$

The EUROMOD is then used to calculate monthly income taxes, social security and health contributions paid, and welfare benefits received for all household members for the situation of the woman working (based on predicted wage) and not working (zero wage). Benefits included in the PTR computations consist mainly of social assistance benefits (targeted to very low income households), child-related benefits, and housing benefits. ${ }^{19}$ Computed taxes, contributions, and welfare benefits and imputed monthly wages are then used in the PTR calculation (see equation 2). The same procedure is applied to calculate the PTR for the fixed EU-wide sample of women.

Sample summary statistics of the employment rate, the PTR and the IV for the PTR by country are reported in Table 1 . There are in total over 433,000 women from 26 countries in the sample. The average employment rate of prime-aged women in the sample is $82.5 \%$, but there are large differences across countries with Scandinavian countries having an employment rate over $90 \%$ and Southern Europe

\footnotetext{
${ }^{18}$ The wage regression adjusted for selection term is run for each country and year separately to allow for different determinants of wages across countries and over time. The selection term is identified using dummies for the presence of children of different ages in the household. Other explanatory variables in the monthly wage regression include education, age, marital status, and nationality.

${ }^{19}$ Public pension benefits are ignored in the present study, because the focus is on prime-aged women. I also exclude maternity and parental leave benefits and unemployment benefits from the PTR computation, because the EUROMOD model includes these benefits only in few countries (eligibility for these benefits often depends on employment history, which is not available in the data). Moreover, unemployment benefits represent only a temporary income replacement, and I am more interested in medium to long term work incentive effects.
} 
with very low employment rates (close to $60 \%$ or $70 \%$ ). The average participation tax rate in the sample is $30.2 \%$, but again the PTR differs greatly across countries with Belgium, Denmark, and Slovenia having the highest average participation tax rates (over 40\%), and Cyprus, Greece, and Spain having the lowest average PTR not exceeding $20 \%$. The within-country variations in the PTR are also substantial and are mainly caused by the presence of means-tested benefits and progressive income tax. ${ }^{20}$

Summary statistics of the instrumental variable for the PTR are reported in columns 5 and 6 of Table 1 . The mean of the IV follows quite closely the mean of the PTR in each country, which confirms that the IV captures most of the crosscountry variation in the participation tax rates. The instrumental variable for the PTR has substantially smaller standard deviations than the PTR, because the IV varies only at group-level (while the PTR has an individual-level variation).

Finally, an evidence on time variation in the PTR is provided in Appendix Figure A.1. It illustrates changes in the distribution of the PTR over time separately for each country by plotting a box plot of the PTR for each country-year cell. Clearly, the distribution of the PTR changed substantially over time in all countries with the largest changes coinciding with some of the major tax or transfer reforms - a tax base allowances reform in Belgium in 2008, a flat tax reform in the Czech Republic in 2008, tax system changes in Denmark in 2010, the introduction of Solidarity labor income benefit in France in 2009, an increase in the number of tax brackets in Spain in 2007, etc.

\footnotetext{
${ }^{20}$ For example, there are means-tested child benefits, education benefits, and social assistance benefits in Germany, which in combination with progressive income tax system that treats married couples jointly (thereby increasing marginal tax rates of secondary earners) creates a system with quite high and much dispersed participation tax rates for women. Lithuania provides a good example of a country with a participation tax rate that has low variance. Lithuania applies a flat tax rate system to personal income, and the only means-tested benefit is the social assistance benefit for very low income households.
} 
Table 1: Summary statistics of employment rate and the PTR by country

\begin{tabular}{|c|c|c|c|c|c|c|c|}
\hline & \multirow{2}{*}{\multicolumn{2}{|c|}{$\begin{array}{l}\text { Employment rate } \\
\text { Mean Std. Dev. }\end{array}$}} & $(3)$ & ${ }_{\text {PTR }}^{(4)}$ & \multicolumn{2}{|c|}{$\begin{array}{l}(5) \\
\text { IV for PTR }\end{array}$} & $\begin{array}{c}(7) \\
\text { Observations }\end{array}$ \\
\hline & & & Mean & Std. Dev. & Mean & Std. Dev. & \\
\hline AT & 0.838 & 0.368 & 0.367 & 0.132 & 0.404 & 0.080 & 9,840 \\
\hline $\mathrm{BE}$ & 0.835 & 0.371 & 0.423 & 0.105 & 0.404 & 0.063 & 14,689 \\
\hline BG & 0.901 & 0.298 & 0.242 & 0.135 & 0.236 & 0.065 & 8,781 \\
\hline $\mathrm{CY}$ & 0.775 & 0.418 & 0.109 & 0.152 & 0.106 & 0.071 & 5,385 \\
\hline $\mathrm{CZ}$ & 0.837 & 0.370 & 0.308 & 0.116 & 0.350 & 0.053 & 22,042 \\
\hline $\mathrm{DE}$ & 0.844 & 0.363 & 0.389 & 0.118 & 0.368 & 0.059 & 20,234 \\
\hline DK & 0.981 & 0.136 & 0.468 & 0.136 & 0.550 & 0.066 & 9,550 \\
\hline $\mathrm{EE}$ & 0.895 & 0.306 & 0.234 & 0.106 & 0.245 & 0.030 & 13,917 \\
\hline ES & 0.732 & 0.443 & 0.175 & 0.091 & 0.165 & 0.054 & 34,864 \\
\hline FI & 0.954 & 0.210 & 0.309 & 0.074 & 0.260 & 0.040 & 14,613 \\
\hline FR & 0.905 & 0.294 & 0.330 & 0.126 & 0.347 & 0.088 & 21,315 \\
\hline GR & 0.625 & 0.484 & 0.115 & 0.098 & 0.050 & 0.032 & 13,364 \\
\hline $\mathrm{HU}$ & 0.825 & 0.380 & 0.326 & 0.109 & 0.365 & 0.094 & 20,729 \\
\hline $\mathrm{IE}$ & 0.712 & 0.453 & 0.235 & 0.160 & 0.260 & 0.041 & 5,969 \\
\hline IT & 0.684 & 0.465 & 0.249 & 0.087 & 0.165 & 0.048 & 46,606 \\
\hline LT & 0.894 & 0.308 & 0.250 & 0.084 & 0.242 & 0.042 & 11,780 \\
\hline LU & 0.740 & 0.439 & 0.394 & 0.183 & 0.427 & 0.063 & 9,585 \\
\hline LV & 0.904 & 0.294 & 0.298 & 0.050 & 0.299 & 0.027 & 11,185 \\
\hline NL & 0.886 & 0.318 & 0.316 & 0.102 & 0.367 & 0.049 & 22,220 \\
\hline $\mathrm{PL}$ & 0.783 & 0.412 & 0.311 & 0.090 & 0.309 & 0.034 & 26,860 \\
\hline $\mathrm{PT}$ & 0.818 & 0.386 & 0.270 & 0.139 & 0.375 & 0.091 & 9,373 \\
\hline $\mathrm{RO}$ & 0.706 & 0.456 & 0.313 & 0.097 & 0.304 & 0.027 & 11,245 \\
\hline $\mathrm{SE}$ & 0.963 & 0.189 & 0.334 & 0.106 & 0.324 & 0.036 & 13,848 \\
\hline SI & 0.953 & 0.213 & 0.418 & 0.060 & 0.484 & 0.062 & 25,195 \\
\hline SK & 0.905 & 0.293 & 0.327 & 0.181 & 0.347 & 0.067 & 14,643 \\
\hline UK & 0.825 & 0.380 & 0.348 & 0.176 & 0.230 & 0.049 & 15,775 \\
\hline Total & 0.825 & 0.380 & 0.302 & 0.138 & 0.299 & 0.123 & 433,607 \\
\hline
\end{tabular}

Notes: The sample includes women aged $25-55$, who are not in full-time education, are not pensioners, disabled, or self-employed, and do not have a child younger than 1 . The number of observation for each country differs due to differences in sample sizes, but also due to the different number of years covered in different countries (see Appendix Table A.1).

Source: EUROMOD and EU-SILC data (2005-2010), own calculations.

\section{Results}

\subsection{Female labor supply responsiveness to tax-transfer changes}

First, I report results of the first stage regressions, which indeed confirms the strength of the instrumental variable (see Table 2). The instrumental variable is highly significant in both the specification with and without country-year fixed ef- 
fects. $R^{2}$ exceeds 0.4 and the first stage $\mathrm{F}$ statistic is very high (above 700), so that the null hypothesis of a weak instrument is rejected (Stock, Wright, \& Yogo, 2002).

Table 2: First stage regression results

\begin{tabular}{lcc}
\hline \hline & $(1)$ & $(2)$ \\
& Dependent & var.: PTR \\
\hline PTR_IV & $0.601^{* * *}$ & $0.602^{* * *}$ \\
& $(0.013)$ & $(0.014)$ \\
country-year fixed effects & no & yes \\
\hline$R^{2}$ & 0.400 & 0.406 \\
F & 1107.431 & 710.403 \\
Observations & 433,607 & 433,607 \\
\hline \hline
\end{tabular}

Notes: All regressions include a full set of country dummies, year dummies, and control variables. Standard errors in parentheses are clustered at country-year-group level, where groups are defined by education, presence of children of various ages, and marital status $\left(* \mathrm{p}<0.10,{ }^{* *} \mathrm{p}<0.05,{ }^{* * *}\right.$ $\mathrm{p}<0.01)$.

Source: EUROMOD model and EU-SILC data (2005-2010), own calculations.

The main results of the female participation responsiveness towards the PTR are reported in Table 3. The OLS effect of the participation tax rate on an employment decision is reported in the first two columns of Table 3. The effect is negative and significant at $1 \%$ and suggests that an increase of the PTR by 10 percentage points decreases employment probability by 0.6 percentage points. The implied OLS elasticity of participation decision towards the PTR is $0.02 .{ }^{21}$

The 2SLS approach also implies a significant negative impact of the PTR on participation, but the magnitude of the estimated PTR effect is more than three times higher than in the OLS estimation, which confirms the presence of attenuation bias caused by measurement error and endogeneity of income in the OLS estimation. ${ }^{22}$ The 2SLS estimation implies that an increase in the PTR by 10 percentage points

\footnotetext{
${ }^{21}$ All reported elasticities are elasticities at the mean of the independent variables. They are defined as the corresponding PTR coefficient multiplied by the mean of the PTR over the mean of an employment rate.

${ }^{22}$ The income endogeneity in the OLS estimation is also likely to cause a downwards bias. In most countries, the participation tax rate increases with the woman's and her husband's wages, which are both positively correlated to the woman's employment probability (through assortative matching). Therefore, the OLS estimates are likely to be biased downwards, because they include this endogenous positive correlation between the woman's PTR and her participation probability.
} 
Table 3: Estimates of the participation equation

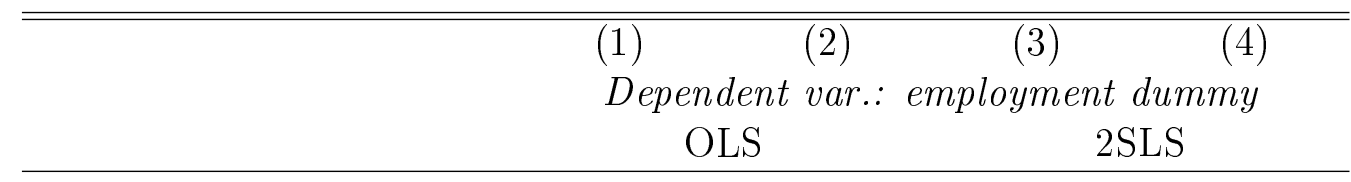

Panel A. Estimation results

$\begin{array}{lcccc}\text { PTR } & -0.060^{* * *} & -0.061^{* * *} & -0.188^{* * *} & -0.208^{* * *} \\ & (0.009) & (0.008) & (0.039) & (0.030) \\ \text { country-year fixed effects } & \text { no } & \text { yes } & \text { no } & \text { yes } \\ R^{2} & 0.174 & 0.175 & 0.173 & 0.173 \\ \text { Observations } & 433,607 & 433,607 & 433,607 & 433,607\end{array}$

Panel B. Elasticity of employment to PTR

$\begin{array}{lllll}\text { Implied elasticity } \quad-0.022 & -0.022 & -0.069 & -0.076\end{array}$

Notes: All regressions include a full set of country dummies, year dummies, and control variables. Standard errors in parentheses are clustered at country-year-group level, where groups are defined by education, presence of children of various ages, and marital status $\left(* \mathrm{p}<0.10,{ }^{* *} \mathrm{p}<0.05, * * *\right.$ $\mathrm{p}<0.01$ ). Panel A reports estimation results of equations 3 (OLS) and 5 (2SLS). Panel B reports the corresponding elasticity of employment to the PTR at the mean of independent variables.

Source: EUROMOD model and EU-SILC data (2005-2010), own calculations.

decreases employment probability by 2 percentage points (see columns 3 and 4 of Table 3). The implied elasticity of labor supply with respect to the participation tax rate for the 2SLS estimates is 0.08 for the specification with country-year fixed effects (a 10\% increase in the PTR decreases employment probability by $0.8 \%$ ). Both the OLS and 2SLS results are very robust to the inclusion of country-year fixed effects, which allow for country-specific changes in preferences and tastes for work as well as country-level changes in policies. Estimated coefficients of the control variables have the expected signs (see Appendix Table A.3).

\subsection{Heterogeneity in the labor supply responsiveness}

This section investigates the heterogeneity in responsiveness across groups of women by their education, family composition, and by groups of countries. I report how the 2SLS estimates of the PTR effect on female participation differ by woman's 
education in Panel A of Table 4. The effect of the PTR is largest for the secondary educated women, for whom the 10 percentage point increase in the PTR decreases employment probability by 4.3 percentage points (the corresponding elasticity is 0.16). Both women with primary and tertiary education seem to be much less responsive to tax changes (an elasticity of 0.04 for both groups), but the effect is not significantly different from zero for women with primary education (possibly due to a small sample size). The non-linear relationship between the education and labor supply elasticity might be caused by a combination of two factors. On the one hand, less educated women have a lower employment rate (the means of the dependent variable can be found in the last column of Table 4), which usually implies larger employment elasticity. On the other hand, women with primary education tend to live in households with very low incomes, so that their participation on the labor market might be a necessity.

Panel B of Table 4 illustrates the differences in female labor supply responsiveness according to a woman's marital status and family composition. Married and cohabiting women are overall more responsive to tax and transfer changes than single women, which is a finding consistent with most previous studies (see, e.g. Bargain et al., 2014). The estimated PTR elasticity is 0.08 for married and cohabiting women and 0.06 for single women. However, when splitting the two groups by the presence of small children up to 5 years of age, a slightly different picture emerges. Single women with small children have by far the highest participation elasticity of 0.32 , which is consistent with previous findings, where lone mothers are the demographic group with the highest participation elasticity (Meghir \& Phillips, 2008). Married and cohabiting women with small children also have a very large participation elasticity of 0.16 , while both single and coupled women without small children have a substantially lower responsiveness towards tax and transfer changes (corresponding elasticities of 0.06 and 0.05 for coupled and single women, respectively).

Finally, I investigate the heterogeneity of the effect of the PTR on participa- 
Table 4: Estimates of the participation equation: heterogeneity of responses

\begin{tabular}{|c|c|c|c|c|}
\hline & \multicolumn{4}{|c|}{$\begin{array}{l}\text { Dependent var.: employment dummy } \\
\text { 2SLS }\end{array}$} \\
\hline & PTR (coeff.) & PTR (elast.) & $\mathrm{N}$ & dep. mean \\
\hline \multicolumn{5}{|c|}{ Panel A. The PTR effect by woman's education } \\
\hline Primary education & $\begin{array}{l}-0.093 \\
(0.104)\end{array}$ & -0.043 & 25,322 & 0.528 \\
\hline Secondary education & $\begin{array}{c}-0.429^{* * *} \\
(0.041)\end{array}$ & -0.161 & 250,280 & 0.796 \\
\hline Tertiary education & $\begin{array}{c}-0.125^{* * *} \\
(0.033)\end{array}$ & -0.043 & 158,005 & 0.919 \\
\hline \multicolumn{5}{|c|}{ Panel B. The PTR effect by family structure } \\
\hline Married and cohabiting & $\begin{array}{c}-0.219^{* * *} \\
(0.037)\end{array}$ & -0.083 & 330,216 & 0.799 \\
\hline - with small children & $\begin{array}{c}-0.366^{* * *} \\
(0.071)\end{array}$ & -0.160 & 74,787 & 0.694 \\
\hline - without small children & $\begin{array}{c}-0.176^{* * *} \\
(0.042)\end{array}$ & -0.064 & 255,429 & 0.830 \\
\hline Single & $\begin{array}{c}-0.180^{* * *} \\
(0.037)\end{array}$ & -0.059 & 103,391 & 0.909 \\
\hline - with small children & $\begin{array}{c}-0.748^{* * *} \\
(0.151)\end{array}$ & -0.317 & 7,909 & 0.712 \\
\hline - without small children & $\begin{array}{c}-0.143^{* * *} \\
(0.037)\end{array}$ & -0.046 & 95,482 & 0.926 \\
\hline \multicolumn{5}{|c|}{ Panel C. The PTR effect by welfare regime } \\
\hline Social-Democratic & $\begin{array}{c}-0.020 \\
(0.052)\end{array}$ & -0.007 & 38,011 & 0.964 \\
\hline Liberal & $\begin{array}{c}-0.361^{* * *} \\
(0.061)\end{array}$ & -0.144 & 21,744 & 0.794 \\
\hline Conservative-Corporatist & $\begin{array}{c}-0.121^{* * *} \\
(0.046)\end{array}$ & -0.052 & 97,883 & 0.854 \\
\hline Southern-European & $\begin{array}{c}-0.328^{* * *} \\
(0.067)\end{array}$ & -0.095 & 109,592 & 0.708 \\
\hline Post-Communist & $\begin{array}{c}-0.277^{* * *} \\
(0.052)\end{array}$ & -0.108 & 129,495 & 0.847 \\
\hline Former-USSR & $\begin{array}{l}-0.132 \\
(0.261)\end{array}$ & -0.038 & 36,882 & 0.898 \\
\hline
\end{tabular}

Notes: The table reports the PTR coefficients from the 2SLS estimation applied separately to each group of women, the corresponding elasticity of employment to the PTR at the mean of independent variables, number of observations $(\mathrm{N})$, and a mean of the dependent variable for each group. All regressions include a full set of country-year fixed effects and control variables. Standard errors in parentheses are clustered at country-year-group level $(* \mathrm{p}<0.10, * * \mathrm{p}<0.05$, *** $\mathrm{p}<0.01$ ). The division of countries into welfare regimes is as following: DK, FI, SE belong to the social-democratic; IE, UK belong to the liberal; AT, BE, DE, FR, LU, NL belong to the conservative-corporatist; CY, GR, IT, PT, ES belong to the Southern-European; BU, CZ, HU, PL, RO, SI, SK belong to the post-communist; and ES, LT, LV belong to the former-USSR welfare regime.

Source: EUROMOD model and EU-SILC data (2005-2010), own calculations. 
tion by groups of countries. For this purpose, I use a well-known welfare regime typology by Esping-Andersen (1990) that creates groups of countries based on social policies and organization of work. Esping-Andersen (1990) differentiated between three models of the welfare state: the social-democratic, the liberal, and the conservative--corporatist welfare state. This typology was later extended with the Southern-European welfare regime (Ferrera, 1996), and the European postcommunist and former-USSR categories (Fenger, 2007). I use this extended welfare regime categorization of Fenger (2007), which allows the categorizing of all countries in the sample. ${ }^{23}$

Panel C of Table 4 reports the PTR coefficients and elasticities by welfare regime. The participation elasticities are highest in the liberal (0.14), the post-communist (0.11), and the Southern-European (0.10) welfare regimes. These are also the three groups of countries with the lowest female participation. Therefore, the results are consistent with previous findings that elasticities are larger in countries where female participation is lower (Bargain et al., 2014; Blau \& Kahn, 2007). The responsiveness is substantially lower in the conservative-corporatist welfare regime, and not significantly different from zero in the social-democratic and the former-USSR welfare regimes. This is not very surprising given that the female participation rates in these two groups of countries reach $96.4 \%$ and $89.8 \%$, respectively.

Results presented in this section are also in line with Bargain et al. (2014), which is the closest paper to this study. Due to methodological differences and due to the fact that I estimate elasticities with respect to participation tax rates, while Bargain et al. (2014) estimate responsiveness to net wages and non-labor income, a direct comparison of my results with Bargain et al. (2014) is rather difficult. Nevertheless, both studies have found substantially smaller female labor supply elasticities than was found in most of the previous literature (Arellano \& Meghir, 1992; Callan, van Soest, \& Walsh, 2009; Laroque \& Salanié, 2002; van Soest, Das, \& Gong, 2002). Both studies also found a substantial heterogeneity of labor supply elasticities

\footnotetext{
${ }^{23}$ See the note below Table 4 for the division of countries into welfare regimes.
} 
across countries (with the UK and the Southern-European countries being among the largest-elasticity countries), and across groups of women (with the largest participation elasticity among single mothers).

\subsection{Examining the quality of the PTR imputation}

In this section, the quality of the PTR imputation to the EU-SILC data is examined (for details on the imputation, see Section 3.1). To illustrate the impact of the PTR imputation on the estimated coefficients, I compare the results of the participation equation based on the underlying EUROMOD data and based on the EU-SILC data (with the imputed PTR) for the same set of country-year cells. I restrict the sample to all countries, for which the EUROMOD data are available for years 20052007. The comparison of results is provided in Appendix Table A.2. The PTR is highly significant in the 2SLS specification and the magnitude of coefficients is quite similar using both the EUROMOD data and the EU-SILC data with the imputed PTR - the coefficients are -0.52 based on the EUROMOD data and -0.44 based on the EU-SILC in the specification with country-year fixed effects. The elasticities are also quite similar, although again somehow larger in the estimation using the EUROMOD data - elasticity of 0.18 as compared to 0.15 based on the EU-SILC. ${ }^{24}$

The estimated coefficients in the OLS specification are quite different using the EUROMOD data and EU-SILC data. In fact, the results based on the EUROMOD data suggest a positive effect of the PTR on employment probability. Therefore, the magnitude of bias in the OLS estimation seems to be much higher than is suggested by the EU-SILC estimation results (see Appendix Table A.2). Overall, the estimation results based on the EU-SILC data with the imputed PTR thus seem to be somewhat smaller in magnitude than those based on the EUROMOD data suggesting a presence of a downward bias caused by the imputation procedure.

\footnotetext{
${ }^{24}$ The estimated coefficients and elasticities presented here are much larger in magnitude than the estimates presented in Section 4.1. This is because they are based on a selected group of counties for which the EUROMOD data are available for years 2005-2007. This sample selection was mainly driven by the necessity to have a sufficient number of tax and transfer changes in the sample to be able to identify the effect of the PTR on employment decision in the EUROMOD data.
} 
Nevertheless, the main findings stay unchanged whether we use the EUROMOD data or the data with the imputed PTR.

\section{Conclusion}

This paper investigates the impact of tax and transfer policies in the countries of the EU on the extensive margin of female labor supply. Unlike previous studies, I utilize an indicator of extensive margin work incentives - the participation tax rate-as the main explanatory variable. This allows the capturing of the effect of both tax and benefit systems on the work incentives of women and to deal with possible endogeneity of the participation tax rate by using a simulated instrumental variable. The instrumental variable allows me to exploit only the variation in the participation tax rate due to changes in policies setting aside the variation due to measurement error and endogenous behavioral responses. Further, the rich structure of the data, which cover 26 EU countries in 2005-2010, allows me to control for time-invariant, as well as time-varying country-level unobserved factors (such as economic shocks, tastes for work, or family policies), and use all policy changes that took place in these countries between 2005 and 2010 for identification.

The results suggest that the participation decisions of women in the EU are indeed negatively affected by the level of effective taxation they face. The comparison of estimates based on the OLS and the IV approaches confirms the presence of attenuation bias caused by the measurement error and income endogeneity. The instrumental variable estimation implies that a 10 percentage point increase in the participation tax rate decreases the female employment probability by 2 percentage points (the corresponding participation elasticity is 0.08 ). The effect is higher for secondary educated women - results suggest that secondary educated women respond to the 10 percentage point increase in the PTR by decreasing their employment probability by 4.3 percentage points (elasticity of 0.16 ). Women with primary and tertiary education are substantially less responsive to tax and transfer 
incentives (elasticity of 0.04 for both groups).

I also investigate the heterogeneity of responses towards tax and transfer systems across groups of women by their marital status and family composition. The results are in line with previous findings (Bargain et al., 2014; Keane, 2011) - the responsiveness is higher for married women than for single women, for women with small children than for those without small children, and the highest elasticities are found for the group of single mothers (participation elasticity of 0.32).

Further, I use the typology of welfare regimes originally proposed by Esping-Andersen (1990) to uncover the heterogeneity of responses across groups of countries. The results indicate that the effect of the PTR on the employment probability is the highest for the liberal welfare regime (to which Ireland and the UK belong), the post-communist and the Southern-European welfare regimes. These are also the three groups of countries with the lowest female participation rate. Therefore, the findings are consistent with previous findings that suggest that the higher the female labor force participation, the lower the female labor supply elasticity (Blau \& Kahn, 2007).

Bargain et al. (2014) is to my knowledge the only study that uses multinational tax-benefit microsimulation model in the analysis of female labor supply behavior, and is thus closest to the present study. Similar to Bargain et al. (2014), I find much smaller female participation elasticities than some previous studies, and a substantial heterogeneity of elasticities across groups of women and across countries. In particular, single mothers and women living in Southern Europe and the UK have the largest participation elasticities according to both the present study and Bargain et al. (2014). However, the present study takes a different estimation approach and uses a much longer time span than Bargain et al. (2014). My sample also covers 7 post-communist and 3 former-USSR countries, which have been only rarely studied in the female labor supply literature, and from which Bargain et al. (2014) cover only Estonia, Hungary and Poland. My results suggest that the postcommunist countries have one of the highest female participation elasticities, while 
the former-USSR countries belong to the group of countries with the highest female employment and lowest participation elasticities.

Multinational microsimulation models offer a very useful tool for the study of tax and transfer impact on the labor supply, as they allow for a large scale international comparison as well as a comprehensive analysis of heterogeneity in responsiveness across groups of individuals. However, they have been scarcely used in the labor supply elasticity literature. The main shortcoming of these models is a relatively short time span that they cover so far. Therefore, future research should take advantage of a much richer time variation in policies that will be available in the multinational microsimulation models and use it to further reconcile the persisting controversy over the responsiveness of labor supply to tax and transfer changes. 


\section{References}

Arellano, M., \& Meghir, C. (1992). Female labour supply and on-the-job search: an empirical model estimated using complementary data sets. The Review of Economic Studies, 59(3), 537-559.

Bargain, O., Orsini, K., \& Peichl, A. (2014). Comparing labor supply elasticities in Europe and the United States: New results. Journal of Human Resources, $49(3), 723-838$.

Blau, F. D., \& Kahn, L. M. (2007). Changes in the labor supply behavior of married women: 1980-2000. Journal of Labor Economics, 25(3), 393-438.

Blundell, R., Duncan, A., McCrae, J., \& Meghir, C. (2000, March). The labour market impact of the working families' tax credit. Fiscal Studies, 21(1), 75104.

Blundell, R., Duncan, A., \& Meghir, C. (1998). Estimating labor supply responses using tax reforms. Econometrica.

Blundell, R., \& Macurdy, T. (1999). Labor supply: A review of alternative approaches. In Handbook of labor economics.

Blundell, R., Pistaferri, L., \& Saporta-Eksten, I. (2012). Consumption inequality and family labor supply. NBER Working Papers 18445.

Callan, T., van Soest, A., \& Walsh, J. R. (2009, March). Tax structure and female labour supply: Evidence from Ireland. Labour, 23(1), 1-35.

Causa, O. (2009). The policy determinants of hours worked across OECD countries. In Oecd journal: Economic studies (Vol. 2009).

Currie, J., \& Gruber, J. (1996). Health insurance eligibility, utilization of medical care, and child health. The Quarterly Journal of Economics, 111 (2), 431-466.

Cutler, D. M., \& Gruber, J. (1996). Does public insurance crowd out private insurance? The Quarterly Journal of Economics, 111 (2), 391-430.

Dahl, G. B., \& Lochner, L. (2012, August). The impact of family income on child achievement: Evidence from the Earned Income Tax Credit. American Economic Review, 102(5), 1927-1956. 
Devereux, P. (2004). Changes in relative wages and family labor supply. Journal of Human Resources, 39(3), 696-722.

Eissa, N., \& Liebman, J. B. (1996). Labor supply response to the earned income tax credit. The Quarterly Journal of Economics, 111 (2), 605-637.

Esping-Andersen, G. (1990). Three worlds of welfare capitalism (C. Pierson \& F. G. Castles, Eds.). Cambridge: Polity press.

Fenger, H. (2007). Welfare regimes in Central and Eastern Europe: Incorporating post-communist countries in a welfare regime typology. Contemporary Issues and Ideas in Social Sciences, 3(2), 1-30.

Ferrera, M. (1996). The 'Southern model' of welfare in social Europe. Journal of European social policy, 6(1), 17-37.

Gruber, J., \& Saez, E. (2002, April). The elasticity of taxable income: Evidence and implications. Journal of Public Economics, 84(1), 1-32.

Hoynes, H. (1996). Welfare transfers in two-parent families: Labor supply and welfare participation under AFDC-UP. Econometrica, 64(2), 295-332.

Immervoll, H. (2004). Average and marginal effective tax rates facing workers in the EU: A micro-level analysis of levels, distributions and driving factors. OECD Social, Employment and Migration Working Papers No. 19, OECD Publishing.

Keane, M. (2011). Labor supply and taxes: A survey. Journal of Economic Literature, 49(4), 961-1075.

Laroque, G., \& Salanié, B. (2002). Labour market institutions and employment in France. Journal of Applied Econometrics, 17(1), 25-48.

Meghir, C., \& Phillips, D. (2008). Labour supply and taxes. IZA Working Paper No. 3405 .

Meyer, B., \& Rosenbaum, D. (2001). Welfare, the earned income tax credit, and the labor supply of single mothers. The Quarterly Journal of Economics, 116(3), $1063-1114$.

Moffitt, R. A., \& Wilhelm, M. O. (2000). Taxation and the labor supply decisions 
of the affluent. In J. Slemrod (Ed.), Does atlas shrug? economic consequences of taxing the rich (pp. 193-234). New York: Russell Sage Foundation.

Saez, E., Matsaganis, M., \& Tsakloglou, P. (2012, January). Earnings determination and taxes: Evidence from a cohort-based payroll tax reform in Greece. The Quarterly Journal of Economics, 127(1), 493-533.

Stock, J., Wright, J., \& Yogo, M. (2002). A survey of weak instruments and weak identification in generalized method of moments. Journal of Business $\mathscr{E}$ Economic Statistics, 20(4), 518-29.

Sutherland, H. (2007). EUROMOD - The tax-benefit microsimulation model for the European Union. In A. Harding (Ed.), Modelling our future: Population ageing, health and aged care (pp. 483-488). Emerald Group Publishing Limited.

van Soest, A. (1995). Structural models of family labor supply: A discrete choice approach. The Journal of Human Resources, 30(1), 63.

van Soest, A., Das, M., \& Gong, X. (2002). A structural labour supply model with flexible preferences. Journal of Econometrics, 107(1), 345-374. 


\section{Appendix}

Table A.1: Overview of country-year cells used in the analysis

\begin{tabular}{l|cccccc|ccc}
\hline \hline & \multicolumn{7}{|c|}{ Tax-benefit rules } & \multicolumn{3}{|c}{ Input data } \\
& 2005 & 2006 & 2007 & 2008 & 2009 & 2010 & 2005 & 2006 & 2007 \\
\hline AT & & & $\mathrm{x}$ & $\mathrm{x}$ & $\mathrm{x}$ & $\mathrm{x}$ & & & $\mathrm{x}$ \\
BE & $\mathrm{x}$ & $\mathrm{x}$ & $\mathrm{x}$ & $\mathrm{x}$ & $\mathrm{x}$ & $\mathrm{x}$ & $\mathrm{x}$ & $\mathrm{x}$ & $\mathrm{x}$ \\
BG & & & $\mathrm{x}$ & $\mathrm{x}$ & $\mathrm{x}$ & $\mathrm{x}$ & & & $\mathrm{x}$ \\
CY & & $\mathrm{x}$ & $\mathrm{x}$ & $\mathrm{x}$ & & & & $\mathrm{x}$ & $\mathrm{x}$ \\
CZ & $\mathrm{x}$ & $\mathrm{x}$ & $\mathrm{x}$ & $\mathrm{x}$ & $\mathrm{x}$ & $\mathrm{x}$ & $\mathrm{x}$ & $\mathrm{x}$ & $\mathrm{x}$ \\
DE & & & $\mathrm{x}$ & $\mathrm{x}$ & $\mathrm{x}$ & $\mathrm{x}$ & & & $\mathrm{x}$ \\
DK & & & $\mathrm{x}$ & $\mathrm{x}$ & $\mathrm{x}$ & $\mathrm{x}$ & & & $\mathrm{x}$ \\
EE & $\mathrm{x}$ & $\mathrm{x}$ & $\mathrm{x}$ & $\mathrm{x}$ & $\mathrm{x}$ & $\mathrm{x}$ & $\mathrm{x}$ & $\mathrm{x}$ & $\mathrm{x}$ \\
FI & & & $\mathrm{x}$ & $\mathrm{x}$ & $\mathrm{x}$ & $\mathrm{x}$ & & & $\mathrm{x}$ \\
FR & & $\mathrm{x}$ & $\mathrm{x}$ & $\mathrm{x}$ & $\mathrm{x}$ & $\mathrm{x}$ & & $\mathrm{x}$ & \\
GR & $\mathrm{x}$ & $\mathrm{x}$ & $\mathrm{x}$ & $\mathrm{x}$ & $\mathrm{x}$ & $\mathrm{x}$ & $\mathrm{x}$ & $\mathrm{x}$ & $\mathrm{x}$ \\
ES & $\mathrm{x}$ & $\mathrm{x}$ & $\mathrm{x}$ & $\mathrm{x}$ & $\mathrm{x}$ & $\mathrm{x}$ & $\mathrm{x}$ & $\mathrm{x}$ & $\mathrm{x}$ \\
HU & & $\mathrm{x}$ & $\mathrm{x}$ & $\mathrm{x}$ & $\mathrm{x}$ & $\mathrm{x}$ & & $\mathrm{x}$ & $\mathrm{x}$ \\
IE & & $\mathrm{x}$ & $\mathrm{x}$ & $\mathrm{x}$ & & & & $\mathrm{x}$ & $\mathrm{x}$ \\
IT & $\mathrm{x}$ & $\mathrm{x}$ & $\mathrm{x}$ & $\mathrm{x}$ & $\mathrm{x}$ & $\mathrm{x}$ & $\mathrm{x}$ & $\mathrm{x}$ & $\mathrm{x}$ \\
LT & $\mathrm{x}$ & $\mathrm{x}$ & $\mathrm{x}$ & $\mathrm{x}$ & $\mathrm{x}$ & $\mathrm{x}$ & $\mathrm{x}$ & & $\mathrm{x}$ \\
LU & & & $\mathrm{x}$ & $\mathrm{x}$ & $\mathrm{x}$ & $\mathrm{x}$ & & & $\mathrm{x}$ \\
LV & & $\mathrm{x}$ & $\mathrm{x}$ & $\mathrm{x}$ & $\mathrm{x}$ & $\mathrm{x}$ & & $\mathrm{x}$ & $\mathrm{x}$ \\
NL & & $\mathrm{x}$ & $\mathrm{x}$ & $\mathrm{x}$ & $\mathrm{x}$ & $\mathrm{x}$ & & $\mathrm{x}$ & $\mathrm{x}$ \\
PL & & $\mathrm{x}$ & $\mathrm{x}$ & $\mathrm{x}$ & $\mathrm{x}$ & $\mathrm{x}$ & & $\mathrm{x}$ & $\mathrm{x}$ \\
PT & & $\mathrm{x}$ & $\mathrm{x}$ & $\mathrm{x}$ & $\mathrm{x}$ & $\mathrm{x}$ & & $\mathrm{x}$ & $\mathrm{x}$ \\
RO & & & $\mathrm{x}$ & $\mathrm{x}$ & $\mathrm{x}$ & $\mathrm{x}$ & & & $\mathrm{x}$ \\
SE & & $\mathrm{x}$ & $\mathrm{x}$ & $\mathrm{x}$ & $\mathrm{x}$ & $\mathrm{x}$ & & $\mathrm{x}$ & $\mathrm{x}$ \\
SI & & $\mathrm{x}$ & $\mathrm{x}$ & $\mathrm{x}$ & $\mathrm{x}$ & $\mathrm{x}$ & & $\mathrm{x}$ & $\mathrm{x}$ \\
SK & & $\mathrm{x}$ & $\mathrm{x}$ & $\mathrm{x}$ & $\mathrm{x}$ & $\mathrm{x}$ & & $\mathrm{x}$ & $\mathrm{x}$ \\
UK & & $\mathrm{x}$ & $\mathrm{x}$ & $\mathrm{x}$ & $\mathrm{x}$ & $\mathrm{x}$ & & & $\mathrm{x}$ \\
\hline \hline
\end{tabular}

Notes: Table illustrates for which country-year cells the EUROMOD tax-benefit computations are available and for which cells the EUROMOD input data are available. The main results are based on all country-year cells, for which the tax-benefit rules are available. 
Table A.2: Comparison of results based on EUROMOD data and EU-SILC data with the imputed PTR

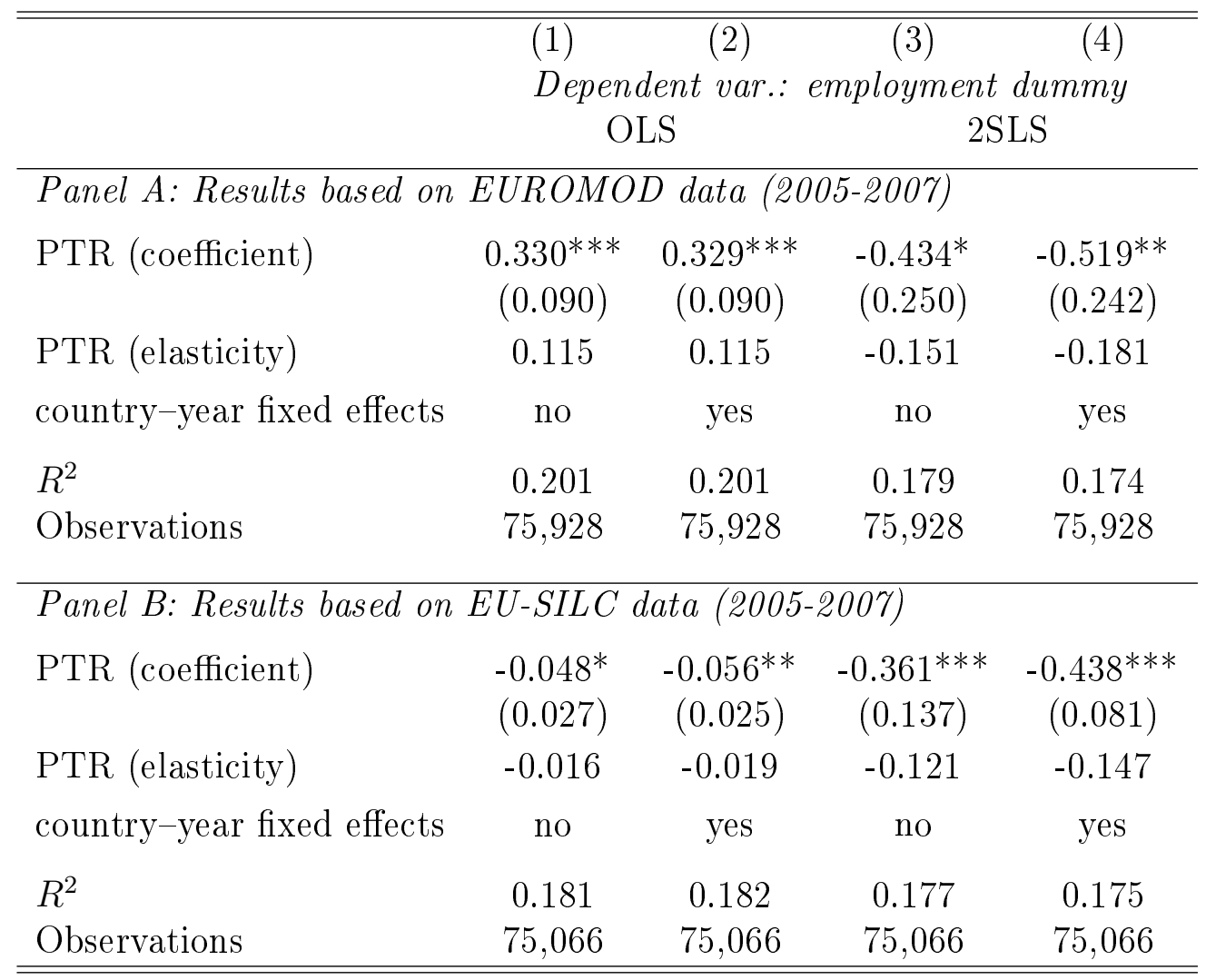

Notes: All regressions include a full set of country dummies, year dummies, and control variables. The sample is restricted to the same set of country-year cells for both samples - to all countries, which have years 2005-2007 covered in the EUROMOD input data. Standard errors in parentheses are clustered at country-year-group level, where groups are defined by education, presence of children of various ages, and marital status $\left(* \mathrm{p}<0.10,{ }^{* *} \mathrm{p}<0.05, * * * \mathrm{p}<0.01\right)$.

Source: EUROMOD and EU-SILC data (2005-2007), own calculations. 
Table A.3: Estimates of the participation equation, full specification

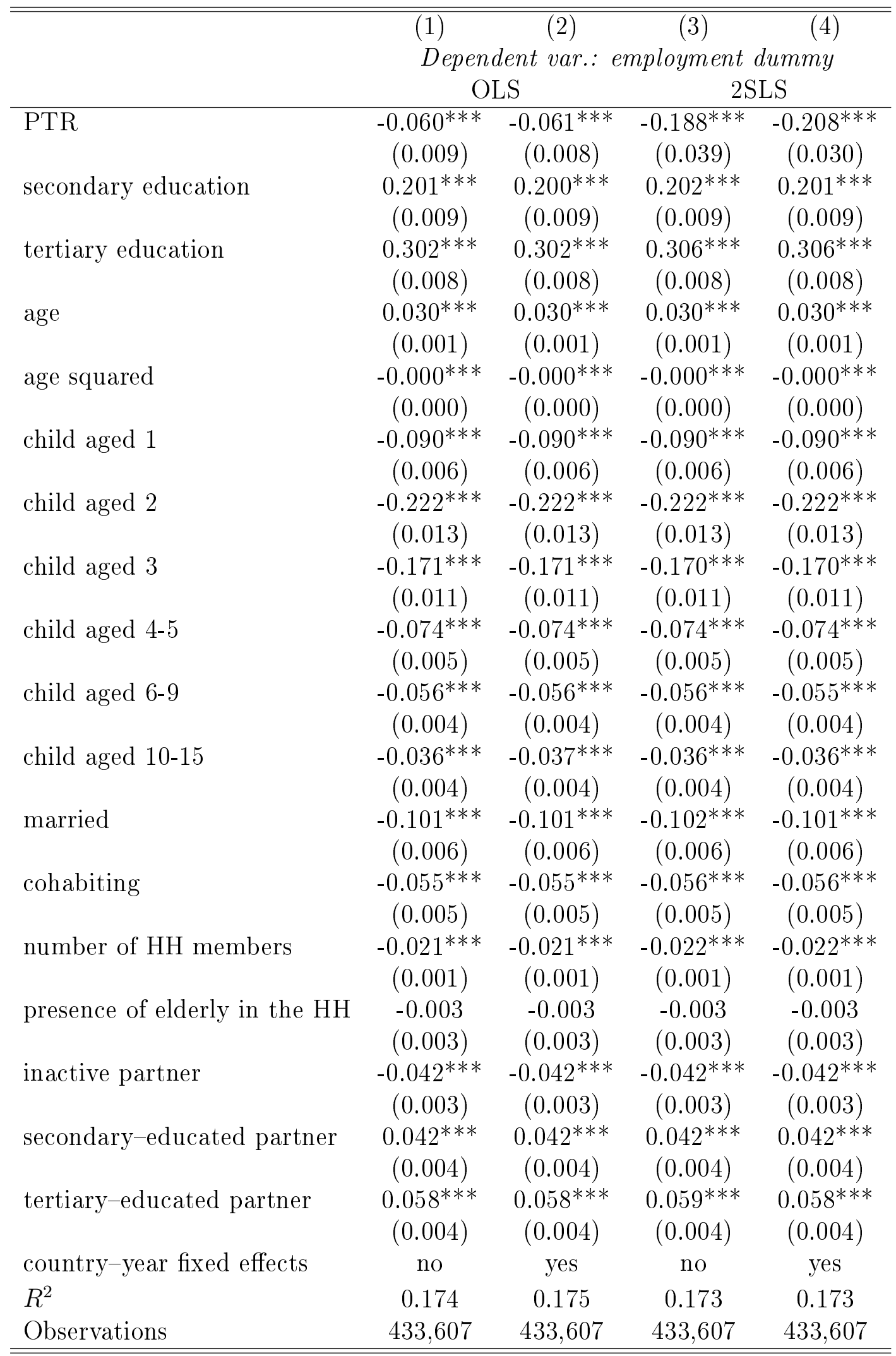

Notes: All regressions include a full set of country and year dummies. Standard errors in parentheses are clustered at country-year-group level, where groups are defined by education, presence of children of various ages, and marital status $\left(* \mathrm{p}<0.10,{ }^{* *} \mathrm{p}<0.05, * * * \mathrm{p}<0.01\right)$. Source: EUROMOD model and EU-SILC data (2005-2010), own calculations. 


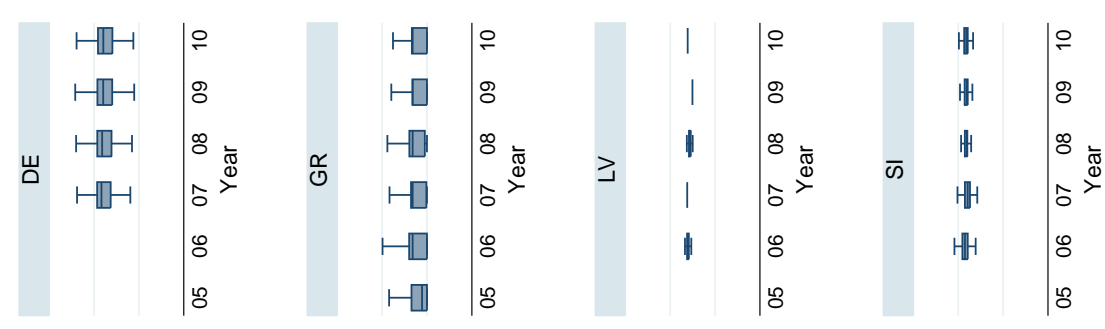

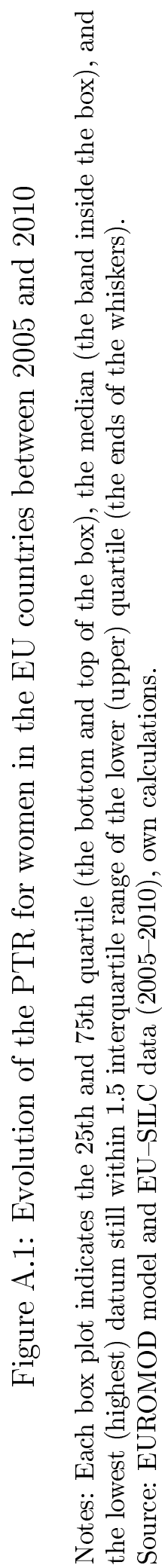




\section{Working Paper Series}

ISSN 1211-3298

Registration No. (Ministry of Culture): E 19443

Individual researchers, as well as the on-line and printed versions of the CERGE-EI Working Papers (including their dissemination) were supported from institutional support RVO 67985998 from Economics Institute of the ASCR, v. v. i.

Specific research support and/or other grants the researchers/publications benefited from are acknowledged at the beginning of the Paper.

(c) Klára Kalíšková, 2014

All rights reserved. No part of this publication may be reproduced, stored in a retrieval system or transmitted in any form or by any means, electronic, mechanical or photocopying, recording, or otherwise without the prior permission of the publisher.

Published by

Charles University in Prague, Center for Economic Research and Graduate Education (CERGE) and

Economics Institute of the ASCR, v. v. i. (EI)

CERGE-El, Politických vězňů 7, 11121 Prague 1, tel.: +420 224005 153, Czech Republic.

Printed by CERGE-EI, Prague

Subscription: CERGE-EI homepage: http://www.cerge-ei.cz

Phone: + 420224005153

Email: office@cerge-ei.cz

Web: http://www.cerge-ei.cz

Editor: Marek Kapička

The paper is available online at http://www.cerge-ei.cz/publications/working_papers/.

ISBN 978-80-7343-329-1 (Univerzita Karlova. Centrum pro ekonomický výzkum a doktorské studium)

ISBN 978-80-7344-321-4 (Akademie věd České republiky. Národohospodářský ústav) 
CERGE-EI

P.O.BOX 882

Politických vězňů 7

11121 Praha 1

Czech Republic http://www.cerge-ei.cz 